Saudi Journal of Biomedical Research

Abbreviated Key Title: Saudi J Biomed Res ISSN 2518-3214 (Print) |ISSN 2518-3222 (Online)

\title{
Measurement of Serum Uric Acid, Calcium and Phosphate Pre and Post Hemodialysis
}

Shaza Hassan Yahia*

Lecturer at Nahda College, Department of Clinical Chemistry, Medical Laboratory, Sudan

DOI: $10.36348 /$ sjbr.2019.v04i12.006

| Received: 18.12.2019 | Accepted: 25.12.2019 | Published: 28.12.2019

*Corresponding author: Shaza Hassan Yahia

\section{Abstract}

This study was done to estimate the serum uric acid, phosphate and calcium level pre and post dialysis. To do these 50 patients with chronic renal failure and 20 apparently healthy individuals as control group were involved. Uric acid, calcium and phosphate level was determined for all patients and the control group and the result was analyzed using spss package. The mean of uric acid pre dialysis is significantly raised compared with that of the control group $(9.4 \pm 2.3$ versus $3.9 \pm 0.9) \mathrm{mg} / \mathrm{dl}$. And the mean of uric acid level post dialysis decreased after dialysis compared with that of before dialysis $(2.9 \pm 1.3$ versus $9.4 \pm 2.3) \mathrm{mg} / \mathrm{dl}$ and P.value 0.00 . The mean of calcium pre dialysis is significantly decreased compared with that of the control group (5.4 0.85 versus $9.8 \pm 0.8) \mathrm{mg} / \mathrm{dl}$. And the mean of calcium level post dialysis decreased after dialysis compared with that of before dialysis $(4.4 \pm 1.07$ versus $5.4 \pm 0.85) \mathrm{mg} / \mathrm{dl}$. The mean of phosphate pre dialysis is significantly raised compared with that of the control group $(5.7 \pm 2.04$ versus $3.7 \pm 0.46) \mathrm{mg} / \mathrm{dl}$. And the mean of phosphate level post dialysis decreased after dialysis compared with that of before dialysis (3.1 $\pm 1.3 \mathrm{versus}$ $5.7 \pm 2.04) \mathrm{mg} / \mathrm{dl}$ and P.value 0.00. In the test group, serum uric acid, phosphate and calcium were no correlated with the duration of the disease.

Keywords: Serum Uric Acid, Calcium and Phoshate, Hemodialysis.

Copyright @ 2019: This is an open-access article distributed under the terms of the Creative Commons Attribution license which permits unrestricted use, distribution, and reproduction in any medium for non-commercial use (NonCommercial, or CC-BY-NC) provided the original author and source are credited.

\section{INTRODUCTION}

Chronic renal failure (CRF) is a clinical syndrome that occurs when there is gradual decline of renal function over time. With renal failure there are many physiology derangement of homeostasis of water and minerals (sodium, potassium, chloride, calcium phosphate, magnesium, and sulphate) [1-7].

In 2004 chronic renal failure was found to be the $10^{\text {th }}$ cause of death in Sudan it accounts for about $2 \%$ of death. In 2005, the $6^{\text {th }}$ cause of death in Sudan it accounts about $4 \%$ of death, this indicates the number of death due to chronic renal failure is increasing [7$10]$.

Dialysis is used in cases of acute renal failure to improve the renal function, it may also used to prepare patient with chronic renal failure for transplantation, Dialysis to remove urea and other toxic substances from the plasma and correct electrolyte balance by dialyzing patient blood against fluid containing no urea and appropriate concentration of electrolytes, free ionized calcium and other plasma constituents [11-12].
Several studies were conducted to asses the effect of haemodialysis on serum levels of phosphate and urate in patients with chronic renal failure. The results of those studies were because of the differences in the number of dialysis per week and also the duration of dialysis [13].

\section{MATERIALS AND METHODS}

Study Design: It is a Descriptive hospital base study.

Study Area: The study was done in IBN SINA Hospital, Khartoum state, Sudan.

Study Period: The study was carried during the period from March and June 2014.

Target Population: Sudanese patients with chronic renal failure (males and females).

\section{Inclusion Criteria and Exclusion}

- Inclusion criteria people whom have chronic renal failure 
- Exclusion criteria people who have gout, hypertension and DM and bone diseases.

Sample Size: 50 patients with chronic renal failure.

\section{Ethical Consideration}

- Permission of this study was obtained from the local authorities in the area of the study.

- The objectives of the study were explained to all individuals participating in the study.

- An informed consent was obtained from each participant in the study.

\section{Sampling}

$2.5 \mathrm{ml}$ of venous blood collected in plain container immediately centrifuge at $3000 \mathrm{rpm}$ for 5 minutes to separate serum for investigation of uric acid, calcium and phosphate and stored at $-210 \mathrm{C}$ until used.

\section{METHOD}

\section{Uric Acid}

Estimation of Uric Acid (Enzymatic Method):

Principle: (Uricase IPAP method)

Uricase converts uric acid to allantoin and hydrogen peroxide, the hydrogen peroxide formed further reacts with phenolic compound and 4-amino antipyrine by catalytic action of peroxidase to form a red colored quinoneimine dye complex.

Intensity of the color formed is directly proportional to the amount of uric acid present in the sample [14].

\section{Calcium}

Estimation of calcium by O-CPC method :( Ocresolphthalein complex)

\section{Principle}

Calcium in the sample reacts with ocresolphathalein complexone (o-CPC) produce A coloured complex measure spectrophotometry at 560 $\mathrm{nm}[15]$.

\section{Phosphorus} method:

Estimation of phosphorus by spectrophotometer

\section{Principle}

Inorganic phosphorus in the sample reacts with ammonium molybdate in acidic media to give phosphmolybdate complex that can measure spectrophotometer at $340 \mathrm{~nm}$ [16].

\section{RESULTS}

50 patients with chronic renal failure from IBN SINA Hospital were enrolled in the study as a test group and 20 healthy people as controls.
Table-1: Show Sex frequency for patients with chronic renal failure

\begin{tabular}{|l|l|l|}
\hline Sex & No & Percent \\
\hline Male & 29 & 58 \\
\hline Female & 21 & 42 \\
\hline Total & 50 & 100 \\
\hline
\end{tabular}

Table-2: Show mean of Age, minimum and maximum

\begin{tabular}{|l|l|l|l|}
\hline & Mean & Minimum & Maximum \\
\hline Age & 50 & 24 & 79 \\
\hline
\end{tabular}

Table-3: Show Age group

\begin{tabular}{|l|l|l|}
\hline & Frequency & Percent \\
\hline $20-40$ & 14 & 28 \\
\hline $40-60$ & 22 & 44 \\
\hline $60-80$ & 14 & 28 \\
\hline Total & 50 & 100 \\
\hline
\end{tabular}

Table-4: Show mean of serum uric acid (mg/dl) in patients with chronic renal failure before dialysis compare with control

\begin{tabular}{|l|l|l|l|}
\hline \multirow{2}{*}{ Uric acid $(\mathrm{mg} / \mathrm{dl})$} & \multicolumn{2}{|l|}{ Mean \pm SD } & P.value \\
\cline { 2 - 3 } & control & Pre dialysis & 0.00 \\
\cline { 2 - 3 } & $3.9 \pm 0.9$ & $9.4 \pm 2.3$ & \\
\end{tabular}

Independent $\mathrm{T}$ test was used.

$\mathrm{P}$ value considered significant level $\leq 0.05$

Table-5: Show mean of serum uric acid (mg/dl) in patients with chronic renal failure before dialysis compare with after dialysis

\begin{tabular}{|c|c|c|}
\hline Uric acid & Mean \pm SD mg Idl & P.value \\
\hline Pre dialysis & $9.4 \pm 2.3$ & \multirow[t]{2}{*}{0.00} \\
\hline Post dialysis & $2.9 \pm 1.3$ & \\
\hline
\end{tabular}

Paired sample T test was used.

$\mathrm{P}$ value considered significant level $\leq 0.05$

Table-6: Show mean of serum calcium $(\mathrm{mg} / \mathrm{dl})$ in patients with chronic renal failure before dialysis compare with control

\begin{tabular}{|l|l|l|}
\hline Mean \pm SD & P.value \\
\hline Calcium $(\mathrm{mg} / \mathrm{dl})$ control & Pre dialysis & 0.00 \\
\cline { 1 - 2 } $9.8 \pm 0.8$ & $5.4 \pm 0.85$ & \\
\hline \multicolumn{2}{|c|}{ Paired sample T test was used. }
\end{tabular}

$P$ value considered significant level $\leq 0.05$

Table-7: Show mean of serum calcium $(\mathrm{mg} / \mathrm{dl})$ in patients with chronic renal failure before dialysis compare with after dialysis

\begin{tabular}{|l|l|l|}
\hline Calcium & Mean \pm SD mg Idl & P.value \\
\hline Pre dialysis & $5.4 \pm 0.85$ & 0.00 \\
\cline { 1 - 2 } Post dialysis & $4.4 \pm 1.07$ & \\
\hline
\end{tabular}

Paired sample T test was used.

$P$ value considered significant level $\leq 0.05$ 
Table-8: Show mean of serum phosphate $(\mathrm{mg} / \mathrm{dl})$ in patients with chronic renal failure before dialysis compare with control

\begin{tabular}{|l|l|l|}
\hline \multicolumn{2}{|l|}{ Mean \pm SD } & P.value \\
\hline Phosphate (mg/dl)control & Pre dialysis & 0.00 \\
\cline { 2 - 2 } $3.7 \pm 0.4$ & $5.7 \pm 2.04$ & \\
\hline
\end{tabular}

Paired sample T test was used.

$\mathrm{P}$ value considered significant level $\leq 0.05$

Table-9: Show mean of serum phosphate (mg/dl) in patients with chronic renal failure before dialysis compare with after dialysis

\begin{tabular}{|l|l|l|}
\hline Phosphate & Mean \pm SD mg Idl & P.value \\
\hline Pre dialysis & $5.7 \pm 2.04$ & 0.00 \\
\hline Post dialysis & $3.1 \pm 1.30$ & \\
\hline
\end{tabular}

Paired sample T test was used.

$\mathrm{P}$ value considered significant level $\leq 0.05$

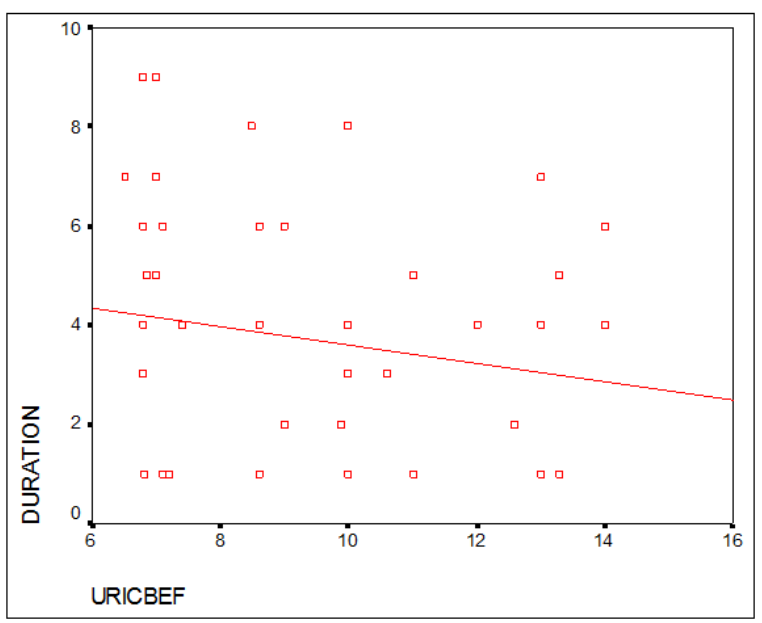

Fig-1: Scatter plot show correlation between duration of disease and Serum uric acid insignificant no correlation (P.value $=0.23 \mathrm{r}$ $=-\mathbf{0 . 1 7})$

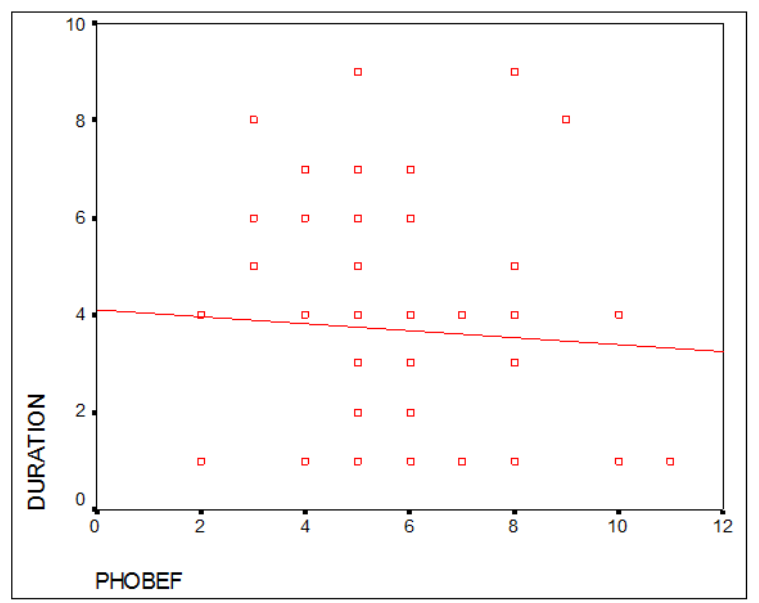

Fig-2: Scatter plot show correlation between duration of disease and Serum phosphate insignificant no correlation (P.value $=0.68$ $\mathbf{r}=\mathbf{- 0 . 0 6 )}$

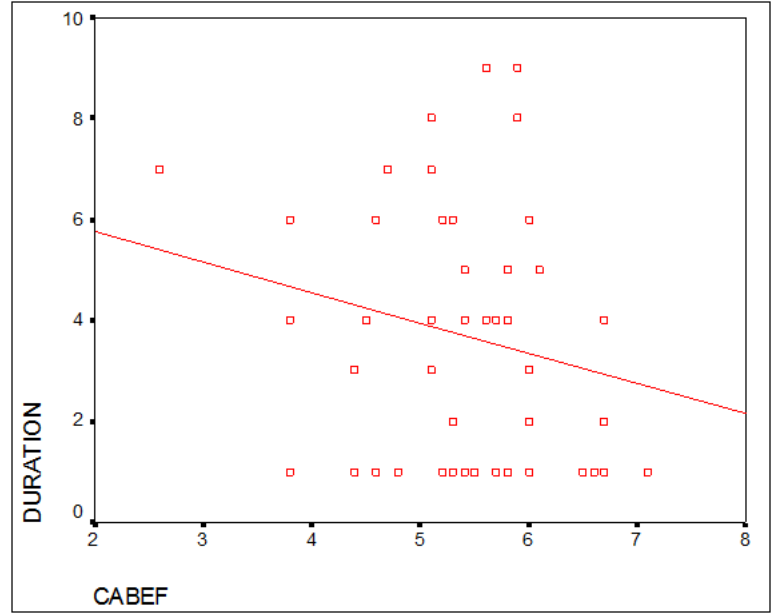

Fig-3: Scatter plot show correlation between duration of disease and Serum calcium insignificant no correlation $(P$.value $=0.14 \mathrm{r}=$ -0.21 )

\section{DISCUSSION}

This study was carry out in IBN SINA Hospital in Khartoum state (Sudan) try to though some light on renal failure patients by estimation of uric acid, calcium and phosphate level in pre dialysis and post dialysis.

The result of this study showed significantly increased in the mean of serum uric acid level in patients $9.4 \pm 2.3 \mathrm{mg} / \mathrm{dL}$ compared with that of the control group $3.9 \pm 0.9 \mathrm{mg} / \mathrm{dL}$ Table-4 and decreased after dialysis $2.9 \pm 1.3 \mathrm{mg} / \mathrm{dL}$ Table-5. This result agrees with study done in Sudan University of science and technology uric acid pre dialysis $7.2 \pm 1.7 \mathrm{mg} / \mathrm{dL}$ compare with post dialysis $4.1 \pm 1.4 \mathrm{mg} / \mathrm{dL}$ July 2009 .

Significantly decreased in the mean of serum calcium level in patients $5.4 \pm 0.85 \mathrm{mg} / \mathrm{dL}$ compared with that of control group $9.8 \pm 0.8 \mathrm{mg} / \mathrm{dL}$ Table- 6 . This result agrees with study done in Sudan University of science and technology calcium level in patients $7.3 \pm$ $0.21 \mathrm{mg} / \mathrm{dL}$ compared with that of control group $10.18 \pm 0.88$ July 2009 and decreased after dialysis $4.4 \pm 1.07 \mathrm{mg} / \mathrm{dL}$ Table-7.

Significantly increased in the mean of serum Phosphate level in patients $5.7 \pm 2.04 \mathrm{mg} / \mathrm{dL}$ compared with that of the control group $3.7 \pm 0.4 \mathrm{mg} / \mathrm{dL}$ Table- 8 and decreased after dialysis $3.1 \pm 1.30 \mathrm{mg} / \mathrm{dL}$ Table- 9 . This result agree with study done in Sudan University of science and technology phosphate level pre dialysis $6.1 \pm 1.7 \mathrm{mg} / \mathrm{dL}$ compared with that of post dialysis $4.3 \pm 0.8 \mathrm{mg} / \mathrm{dL}$ July 2009 .

In the test group, serum uric acid, phosphate and calcium were no correlated with the duration of the disease. 


\section{CONCLUSION}

In this study

- Serum uric acid and phosphate were significantly increased in patients with chronic renal failure.

- Serum calcium was significantly decreased in patients with chronic renal failure.

- Serum levels of calcium, uric acid and phosphate showed no correlation with the duration of the disease.

\section{REFERENCES}

1. Ridge, B. B. (2006). Human physiology, higher Education, Boston Burr Ridge,11 Dubuque,1A Madison $9^{\text {th }}$ edition, 551-552.

2. Jacob, S. T. (2002). Atlas of human anatomy Churchill ST Louis Sydney Toronto $6^{\text {th }}$ edition, 128-134.

3. Bishop, M. L, Fody, E., \& Pand, S. L. (1985). Eclinical chemistry techniqunies principles, correlations wolters kluwery, $6^{\text {th }}$ edition Lippincott and Wilkins, 556-560.

4. Mayn, Z. P. (1994). Clinical chemistry in Diagnosis and treatment Arnold, London. Sydney Auckland co-published in the USA by oxford university press, Inc, New York $5^{\text {th }}$ edition, 2-4.

5. Tietz, N. W. (1987). Fundamentals of clinical chemistry W.B. Saunders Company third edition, 684-686.

6. Marshall, W. J., \& Bangert, S. K. (2004). Clinical chemistry Mosby Edinburgh London New York oxford philaderhia ST Louis Sydney Toronto $5^{\text {th }}$ edition, 184-287.

7. Bishop, M. L., Engel-Kirk, J., \& Land-Fody, E. P. (2000). Clinical chemistry principles, correlations $5^{\text {th }}$ edition Lippincott Williams and Wilkins, 444.

8. Mayn, Z. P. (1994). Clinical chemistry in Diagnosis and treatment Arnold, London. Sydney Auckland co-published in the USA by oxford university press, Inc, New York $6^{\text {th }}$ edition, 173 183.

9. Norbert, W. T. (2001). Tietz fundamentals of clinical chemistry $5^{\text {th }}$ edition. USA, 699:712-720.

10. Arthur C., \& Gwyton, M. D. (2000). Text book of medical physiology $9^{\text {th }}$ edition. USA, 420-425.

11. Bishop, M. L, Fody, E., \& Pand-Schoeff, L. E. (1985). Clinical chemistry techniques principles, correlations wolters kluwery, $6^{\text {th }}$ edition Lippincott and Wilkins, 272.

12. Bushinky, D. A., \& Monk, R. D. (1998). Calcium. Lancet;352:23.

13. Shiber, J. R., \& Mattu, A. (2002). Serum phosphate abnormalities in the emergency department Journal Emerg Med; 23:395-400.

14. Ramink S. (2006). Text book of medical laboratory technology, Jaypee brothers, 649.

15. Lorentz, K. (1982). Improved determination of serum calcium with Aresenazo III. Clinical chemistry Acta, 126:327-334.

16. Gamst, O., \& Try, K. (1980). Determination of serum-phosphate without deproteinization by ultraviolet spectrophotometry of the phosphomolybdic acid complex. Scand Journal Clin Lab Invest, 40:483-486. 